\title{
Family Influence and Firm Performance: The Mediating Role of Stewardship
}

\author{
Catarina Afonso Alves \\ Research Unit for Inland Development \\ Guarda Polytechnic Institute \\ Avenida Francisco Sá Carneiro, 50 \\ 6300-559 Guarda - Portugal \\ calves@ipg.pt
}

\section{Ana Paula Matias Gama}

Research Center in Business Science, NECE

Management and Economics Department of University of Beira Interior

Estrada do Sineiro - Polo IV

6200-209 Covilhã - Portugal

amatias@ubi.pt

\section{Mário Augusto}

University of Coimbra, CeBER, Faculty of Economics,

Av. Dias da Silva, 165

3004-512 Coimbra - Portugal

maugusto@fe.uc.pt

The final version of this article is available online at https://www.emeraldinsight.com/doi/pdfplus/[ https://doi.org/10.1108/JSBED-01-2019-0015]

This manuscript version is made available under the under the Creative Commons Attribution Non-commercial International Licence 4.0 (CC BY-NC 4.0). Reuse is allowed in accordance with the terms outlined by this licence. 
Corresponding author: Mário Augusto 


\section{Family Influence and Firm Performance: The Mediating Role of Stewardship}

\section{Structured abstract}

Purpose - This study examines how stewardship might mediate the influence of family ownership on firm financial performance. We argue that differences in financial performance may reflect not only the family's influence but also the prevalence of a stewardship-oriented culture, across varying degrees of family influence.

Design/methodology/approach-The measure of family influence uses the F-PEC scale: family $[\mathrm{F}]$, power $[\mathrm{P}]$, experience $[\mathrm{E}]$, and culture $[\mathrm{C}]$. It supports cross-firm comparisons of different levels of family influence. To capture the multidimensional nature of family influence, this study uses structural equation modelling and measures the meditating effects of stewardship.

Findings - The results reveal a mediating effect of stewardship; family firms achieve better performance when they take advantage of and encourage stewardship attitudes among owners and leaders. Factors associated with stewardship behaviour, including stewardship motivation and stewardship culture, help explain why some family firms perform better than others.

Practical implications-When analysing the behaviour of family firms, interested entrepreneurs, managers, and consultants should acknowledge that the family's influence entails both financial and emotional capital. The survival of the family businesses depends on balancing these aspects.

Originality-In response to calls for research into mediators of the complex relationship between family influence and firm outcomes, this study provides a novel explanation for performance-maximizing behaviours by organizations, in which pro-organizational attitudes coexist with self-serving motives. 
Keywords—family firms, family influence, stewardship theory, F-PEC, performance. Type-Research paper

\section{Introduction}

Any theory of family firms must account for how the family's involvement influences the firm's performance (e.g., Chrisman et al., 2010), though evidence of the exact influence remains inconclusive (Mazzi, 2011; O'Boyle et al., 2012). In studies of the impact of family ownership on firm performance (e.g., Gama and Galvão, 2012; Kellermanns et al., 2012; Rutherford et al., 2008), some evidence indicates a positive relationship, especially among larger firms, suggesting that family businesses outperform nonfamily businesses (e.g., Anderson and Reeb, 2003; Villalonga and Amit, 2006). In contrast, investigations of smaller family businesses provide less support for this relationship; several performance measures in cross-sectional studies indicate either no significant relationships (e.g., Carney et al., 2015; Sciascia and Mazzola, 2008; Westhead and Howorth, 2006) or nonlinear effects (e.g., Mazzola et al., 2013). These varying results might arise due to differences in existing measures of performance and family influence or else the definitions of family firms (e.g., Chrisman et al., 2012; Rutherford et al., 2008). Theoretically, they suggest the complexity of the relationship, which may be moderated or mediated by factors excluded from previous analyses (Carney et al., 2015; O'Boyle et al., 2012), such that the influence of family ownership on performance is indirect. Noting these inconclusive findings about the benefits of family influence, researchers have called for a greater focus on mediators (e.g., Carney et $a l ., 2015)$. The current study considers the potential mediation of stewardship behaviour, which comprises both motivation and culture.

Specifically, family firms that feature stewardship behaviour and a strong family influence might achieve better financial performance than their nonfamily competitors (e.g., 
Eddleston et al., 2012; Gama and Rodrigues, 2013; Madison et al., 2016). The family businesses are a heterogeneous group of organizations (Anglin et al., 2017). Due the different dimensions of governance choices in family-controlled businesses, Miller and Le Breton-Miller (2006) explain how these dimensions can impact on agency costs and stewardship attitudes and, through them, influence the financial performance of the firm in two ways, directly or through distinctive capabilities. Therefore, differences in financial performance related to a family influence likely interact with the prevalence of stewardshiporiented behaviour within the firm to determine performance. To test this prediction, this study investigates family-owned small to medium-sized enterprises (SMEs), which constitute the vast majority of businesses worldwide (Sharma and Nordqvist, 2008), particularly in the specific study setting of Portugal. Estimates suggest that more than $70 \%$ of all Portuguese firms are family-owned (IFERA, 2003) and more than 60\% of the country's gross domestic product, along with $50 \%$ of employment, is generated by such companies, whose "ownership, whether totally or partially, [is] in the hands of one or more family members, and the family holds control over the management of the company" (AEF, 2019). Not only are most SMEs family owned, but their presence extends across diverse sectors of activity (AEF, 2019). This study setting also is relevant because the relationship between family influence and firm financial performance should be more pronounced in smaller businesses, due to the concentration of ownership and management that characterizes them and that increases the ability of the family, as a dominant coalition, to impose its will. Research interest in privately held, family firms thus results not only from their prevalence but also the notable performance differences they exhibit, relative to larger, listed companies (Carney et al., 2015).

Although studies that compare the performance of family and nonfamily firms are common (e.g., Miller et al., 2008; Villalonga and Amit, 2006), little research addresses how 
family influence as a continuous variable, rather than a dichotomous assessment, might affect firm performance. To expand knowledge about how a family's influence determines firm outcomes, this study explicitly considers the heterogeneity among family firms (Anglin et al., 2017), using a measure of family influence called the F-PEC scale (comprising family $[\mathrm{F}]$, power $[\mathrm{P}]$, experience $[\mathrm{E}]$, and culture $[\mathrm{C}]$ ). This scale supports cross-firm comparisons according to different levels of family influence (Eddleston et al., 2012; Rutherford et al., 2008). Furthermore, noting the multidimensional nature of family influence, this study relies on structural equation modelling (SEM) to examine the relationship between family influence and firm financial performance, as well as the meditating effects of stewardship, conceptualised as stewardship motivation and stewardship culture (Zahra et al., 2008).

As its main theoretical contribution, this study thus proposes and confirms a mediating effect of stewardship: Family firms achieve better performance when they take advantage of and encourage stewardship attitudes among their owners and leaders. The factors associated with stewardship behaviour, including stewardship motivation (i.e., motivation and needs of owner-managers) and stewardship culture (i.e., degree to which stewardship exists in the family firm), accordingly can help explain divergent firm performance, or why some family firms perform better than others. By focusing on family SMEs, these insights, revealing why family firms behave differently, according to their motivations for distinctive behaviour.

In response to calls for research into mediators of the complex relationship between family influence and firm outcomes (Carney et al., 2015), identifying stewardship behaviour as a primary pathway by which family influence affects firm performance (Rau et al., 2018). The next section reviews prior literature to derive the research hypotheses. Section 3 provides details on the data collection, variables, and method, followed by the results in 
Section 4. Following a discussion of the results in Section 5, the final section provides the conclusions, practical implications, and limitations of this study.

\section{Theoretical background, model development, and research hypotheses}

In economic systems worldwide, family firms often are the most common economic organizations (Carney et al., 2015). Their performance and practices thus attract substantial research attention; scholars argue both for and against their superior performance. Although the quantity of research examining the effect of family influence on firm performance has increased (e.g., González-Cruz and Cruz-Ros, 2016; Molly et al., 2019), little consensus exists. Researchers thus express concerns about the ambiguity of the family influence-firm performance relation; according to Litz (1995), the lack of definition of family influence is the primary limitation on further developments in this field. Even studies that examine the link between family influence and firm performance tend to use a simple family versus nonfamily dichotomy (e.g., González-Cruz and Cruz-Ros, 2016; Neubaum et al., 2017). These studies provide important theoretical insights, but a dichotomous characterization is overly simplistic (Astrachan et al., 2002). Furthermore, no well-established set of parameters to describe firms with higher or lower degrees of family influence has emerged (Rau et al., 2018). Yet as Habbershon and Williams (1999) explain, family influence refers to the degree of interaction among the family, firm, and management, reflecting the general question, "How 'family' is a family firm?"

Family firms are characterized by complex arrays of systemic factors that influence their strategy, processes, and performance outcomes (Habbershon et al., 2003; Lussier and Sonfield, 2006). Families influence firm performance primarily through their goals, relationships, and resources, but the potential benefits that translate into higher performance levels depend on the interaction of these factors with business variables. In this sense, 
stewardship behaviour exhibited by family firms might create a competitive advantage, because it evokes pro-organizational, collectivistic behaviours that motivate family members to prioritize firm objectives over their own preferences (Corbetta and Salvato, 2004). In turn, family members and the firm likely can avoid stagnation (Miller et al., 2008). With the prediction that stewardship theory offers a good vantage point for understanding family business dynamics and explaining differences in firm performance (e.g., Eddleston and Kellermanns, 2007; Eddleston et al., 2012), this study investigates how stewardship behaviour might mediate the effect of family ownership on firm financial performance.

\subsection{Family influence and stewardship}

Family involvement, in terms of ownership (percentage of family shares), management (family members on management team), and control (family members on the board of directors; together, these measures constitute the power dimension of F-PEC), is a basic condition for a family to exercise influence and sets a minimum threshold to define a family firm (Chrisman et al., 2005, Muñoz-Bullon et al., 2018). Yet family involvement by itself cannot establish a competitive advantage (or disadvantage) (Le Breton-Miller and Miller, 2013); only through interactions with the organization does it affect value (Chrisman et al., 2005). The complex interactions among the family, its members, and the business constitute a unique bundle of resources that distinguish the family firm and enable it to develop its own resources and competencies, which then determine performance and competitiveness levels (Habbershon et al., 2003). Family involvement should focus on behaviours that produce distinctiveness (Chrisman et al., 2005); together with a transgenerational vision, such behaviours perpetuate firm values (Bozer et al., 2017; Habbershon and Williams, 1999). 
When the firm adopts a trans-generational vision and the family controls the firm, feelings of personal fulfilment arise, so family members likely seek to protect the well-being of the business (Chua et al., 1999), prioritize firm objectives ahead of their own goals, and dedicate their human, social, and financial capital to the firm (Basco, 2017; Zahra et al., 2008). These processes and behaviours transcend ownership and management, supporting the creation of competitive advantages. Therefore, a trans-generational vision is essential to what family firms exemplify; it represents the experience dimension of F-PEC.

Families also can ensure trans-generational sustainability and control by fostering a strong, value-driven organizational culture (Habbershon and Williams, 1999). Through overlaps of the family and business systems, a family identity arises, generating a strong sense of belonging to the family firm (Barnett et al., 2009). Kinship, a shared family name, the common history, and familiarity inspire members to embrace the values and goals of the family firm. The resulting strong identity in family firms helps explain how a distinctive organization identity arises (Zellweger et al., 2010). Therefore, leaders' values are essential to organizational culture, the culture dimension of F-PEC (Klein et al., 2005).

Agency and stewardship theories offer distinct predictions about human behaviour. According to agency theory, human behaviour is rooted in economic rationality (Simon, 1997), and managers are rational actors who seek to maximize individual utility and avoid punishment (Jensen and Meckling, 1976). The company then is a nexus of contracts to motivate, reward, and supervise agents' efforts (Fama and Jensen, 1983). However, according to stewardship theory, people function as stewards who recognise that proorganizational, collectivistic behaviours achieve greater utility than individualistic, selfserving behaviours (Davis et al., 1997). The actor is still rational but perceives greater utility from cooperative behaviours. Because the owners and managers of family businesses have an unusual amount at stake, due to the deep connections between the family and the business, 
stewardship theory might be more relevant in these settings. The steward, unlike an agent, regards the success of the company as a personal achievement (Davis et al., 1997), motivated by intrinsic rewards such as reciprocity and mission alignment, rather than extrinsic rewards.

Not only do such behaviours suggest that some predictions of agency theory might be less applicable to family firms, but stewardship theory also is relevant as a means to describe the behaviour of family firms according the characteristics of their leaders. Family leaders and managers do not set goals merely to maximize their own utility; instead, they altruistically behave as stewards and place the organization's interest above their own to act in the best interest of their principals (Davis et al., 1997). A good steward makes decisions to protect the family's assets, reflecting a desire to pass on a healthy, strong business to future generations (Davis et al., 2010). Family owners also tend to develop deep emotional investments in their companies; their family's fortune, personal satisfaction, and public reputation are tied to the business, and family owners have an incentive to seek long-term benefits for the firm and its stakeholders (Davis et al., 2010). Accordingly, the continuity of family firms is a manifestation of stewardship. Because it arises from the emotional attachment of family members to their business, it likely is unique to family firms, pushing family members to accept the firm's goals and underlying values as their own.

In more detail, stewardship may be manifest in a lifelong commitment to the firm, assiduous management of organizational resources, and competency-creating investments (Davis et al., 1997, 2010), thus smaller family businesses exhibit much care about business longevity and encourage a sustainable relationship with employees and customers (Miller et $a l ., 2008)$. The average CEO's tenure at a family business is $15-25$ years, whereas that for a nonfamily business is 3-4 years (Le Breton-Miller and Miller, 2009; Miller and Le BretonMiller, 2006). Thus, family CEOs are more secure in their jobs and operate with the expectation they will remain in office. This factor alone makes them more far-sighted 
stewards and enables them to take a more involvement-oriented approach to the collective culture, reflecting a stewardship motivation (Davis et al., 1997).

Because they view the business as an extension of the family, family members often go to great lengths to create and maintain a positive organizational identity, so the firm benefits from their involvement and active participation (Zellweger et al., 2010). Family members who share ideas, feedback, and expectations create a common perspective on the business (Eddleston and Kellermanns, 2007), which in turn promotes greater intrinsic motivation (Neubaum et al., 2017). Therefore, our first hypothesis is stated as follows: Hypothesis 1: The components of family influence [(a) power (H1a), (b) experience (H1b), and (c) culture (H1c)] relate positively to a stewardship motivation.

Organizational and cultural conditions, as might reflect a stewardship culture, also have particular relevance for family firms (Davis et al., 1997). Behavioural tendencies might originate with a manager's philosophy (e.g., risk orientation, objectives), psychological mechanisms (e.g., reward motivations, identification, power legitimized by ownership), or situational mechanisms within organizations (e.g., cultural differences such as power distance across different branches and generations of a family). Stewardship culture emerges in behaviours exhibited toward employees and co-workers; such a work environment fosters the talent of people, enlivened by feelings of trust, loyalty, and a strong belief in the corporate culture (Miller and Le Bretton-Miller, 2006). According to prior family business literature, managers and employees in family firms tend to exhibit stronger organizational identification than their counterparts in nonfamily firms and act more collectively (Eddleston and Kellermanns, 2007; Neubaum et al., 2017). As a result, commitment and trust should be high, even among nonfamily members of the firm (James et al., 2017; Madison et al., 2017). Accordingly, 
Hypothesis 2: The components of family influence [(a) power (H2a), (b) experience (H2b), and (c) culture (H2c)] relate positively to a stewardship culture.

\subsection{Stewardship and firm financial performance}

Family firms vary according to the extent and mode of the family's influence on the business (Monreal-Pérez and Sánchez-Marín, 2017; Sharma and Nordqvist, 2008). As noted previously, family influence is necessary but not sufficient to predict the impact of family ownership on firm financial performance. In line with the previous theorizing, this study predicts that stewardship behaviour might be a relevant determinant of family performance (Eddleston and Kellermanns, 2007) and source of competitive advantage (Zahra et al., 2008). In particular, stewardship behaviours arise from a combination of the personal motivations of leaders and the behavioural philosophies that leaders engender within the organization (Davis et al., 1997). Leaders' stewarding motivations are crucial, because they prevent leaders from imprinting their own beliefs on the motivation, reward, and control systems established within imposed by the firm (Davis et al., 1997). A leader with a strong stewardship motivation instead would likely builds an organization with a steward-oriented culture.

Firm culture in turn entails many factors, including the values of its founders, managers, and human resource practices. Human resource practices that emphasize employees' growth and signal managerial support for employees stimulate an involvementoriented rather than individual culture, less power distance, and a corporate governance structure that provides authority and discretion. Such steward-oriented cultures enhance employees' commitment to the organization and its goals; they also create collective responsibility that promotes higher levels of stewardship. For example, external forms of personal, nontangible rewards provided by stewards, such as praise and recognition, increase 
employees' intrinsic motivation through self-actualization mechanisms. Employee trust, commitment to the firm, and prosocial behaviours likely ensue (Pearson and Marler, 2010). In this scenario, nonfamily members also behave as stewards of the family, engaging in supportive and innovative behaviours that benefit the entire organization (Corbetta and Salvato, 2004). Stewardship theory stresses that when employee interests are aligned with those of the organization, employees work diligently to accomplish firm goals (Davis et al., 1997). Their autonomy and involvement in decision making in turn improve organizational performance. In summary, family firms with policies and practices consistent with stewardship behaviours should achieve superior outcomes, including financial performance. Therefore,

Hypothesis 3: Stewardship (a) motivation (H3a) and (b) culture (H3b) relate positively to firm financial performance.

Figure 1 depicts the proposed conceptual framework that guides this research.

[Insert figure 1 about here]

\section{Sample, variables, and method}

\subsection{Sample and data collection}

Self-administered questionnaires were sent to 804 SME family firms, selected from a list maintained by the Instituto de Apoio às Pequenas e Médias Empresas (IAPMEI) in Portugal. These SMEs are defined by the European Union (recommendation 2003/361) to comprise micro, small, and medium-sized categories, such that they employ fewer than 250 people and earn annual turnover that does not exceed EUR 50 million or else an annual balance sheet total that does not exceed EUR 43 million (European Union, 2015). In 2017, SMEs comprised $99.9 \%$ of the enterprises in Portugal and employed $80 \%$ of the people employed in non-financial firms. The identification of a sample of 804 SME family firms 
relied on several criteria. The IAPMEI list only includes SMEs, so determining family firms was the primary goal. A documentary analysis cited the presence of a family surname in the company name or organization chart, based a search of company websites and business association publications, or membership in the Portuguese Family Business Association.

The survey design matched prior research into family business performance and the F-PEC scale (Rutherford et al., 2008). An explicit request asked for family members who held top management positions in firms (e.g., CEO) to complete the questionnaire and FPEC scale, such that they can reveal the ownership stake, family involvement in management, and family governance. Following Chua et al. (1999) and Holt et al. (2010), the power dimension of F-PEC refers to SME family firms that are controlled and managed by one or a few family members, employ immediate family members, and involve the family tacitly in the business.

The 169 completed responses represent a response rate of $21.02 \%$, which is satisfactory considering the nature of the questionnaire and its administration (Chrisman et al., 2012). The test for non-response bias compared the means for each item response obtained from the first 25 answers against the same means for the last 25 answers (e.g., Armstrong and Overton, 1977), using a $t$-test for the equality of means. The $t$-test results show no significant differences (at conventional significance levels of $1 \%$ and 5\%) for any of the 29 items used to measure the model constructs. Thus, nonresponse bias is not a major concern in this study.

The respondents who completed the questionnaires were senior executives; more than $84.6 \%$ indicated they were CEOs, presidents, or board chairs. Their average age was 48 years, and most were men (69\%). Of these leaders, 97\% expected to keep the business under family ownership and control for the next five years. Furthermore, the average age of the businesses was 38 years. About $34 \%$ of the firms represented the first generation, $47 \%$ were 
led by second-generation managers, and $19 \%$ were in the third or later generations. All businesses remained under ownership control of family members; the founding generation still held sole control of $44.6 \%$ of companies. According to standard industry classification codes, the sample includes $46 \%$ manufacturing, $24 \%$ retail, $10 \%$ construction, and $20 \%$ other industry (e.g., agriculture, hotels, and transportation) firms and 66,8\% of companies employ less than 50 employees.

\subsection{Variables}

3.2.1. Exogenous variables. The measure of family influence used the F-PEC scale, developed by Astrachan et al. (2002), validated by Klein et al. (2005) and Holt et al. (2010), and revisited by Rau et al. (2018). It comprises three dimensions:

- Power, measured with three percentages: (1) family share ownership, (2) family on the board of directors, and (3) family on the management team.

- Experience, measured with three items that assess successive generational involvement in ownership, management, and governance by determining how many generations of the family (1) owned the company, (2) managed the company, and (3) were active on the board of directors. Consistent with Astrachan et al. (2002), the first generation takes a value of 0 (i.e., no benefit of generational experience), the second generation .5 , third generation .75 , and fourth generation a value of .875 .

- Culture, or the extent to which the values of the business and family overlap and the family is committed to the business, measured with 11 items. Three items pertain to the extent to which the family influences the business and family values overlap with business values (values), measured on 5 -point Likert scales $(1=$ not at all, $5=$ to a large extent). Four items refer to the family's commitment to the business 
(commitment). The remaining four items measure family engagement, with another 5-point Likert scale $(1=$ strongly disagree, $5=$ strongly agree $)$.

3.2.2. Mediating variables. Following Zahra et al. (2008), both dimensions of stewardship behaviour (i.e., motivation and culture) are measured on 5-point Likert scales ( $1=$ not at all, $5=$ to an extreme extent). According to Davis et al. (1997), these measures reflect the personal and psychological motivations of executives, as well as organizational and cultural conditions. Specifically, stewardship motivation pertains to the motivations and needs of the responding executive; stewardship culture measures the degree to which such a motivation encourages cooperation and involvement, which facilitates a natural alignment of interests across all firm stakeholders. The five items used to measure stewardship motivation indicate the extent to which the respondents value positive, intrinsic motivations, consistent with stewardship-oriented behaviours. For stewardship culture, three items capture the firm's ability to establish governance that is inclusive and the extent to which the firm maintains a collective, supportive, caring environment for employees and provides opportunities for them to reach their potential.

3.2.3. Outcome variables. Because the sample consists only of SMEs, which generally do not report objective performance data, this study relies on subjective performance measures (Eddleston and Kellermanns, 2007). The measure of financial performance asked respondents to compare their performance with that of their main competitors in previous years on four dimensions: sales growth, profit margin, return on asset growth, and return on equity growth (Madison et al., 2017), using 5-point Likert scales ( $1=$ much lower, $5=$ much higher $)$. 


\subsection{Method}

To estimate and evaluate the proposed model (Figure 1), this study adopts the structural equation modelling (SEM), which comprises both a measurement model and a structural model that can be estimated simultaneously or with a two-step approach. This study uses a two-step approach (Anderson and Gerbing, 1988) to obtain the results reported in the next section.

\section{Results}

\subsection{Measurement model}

The estimations rely on a maximum likelihood (ML) method, which assumes multinormality in the distribution of the observed variables. To identify any departures from normality for each observed variable, skewness and kurtosis values are informative. The skewness values range from -4.14 to .00 , and kurtosis ranges from -1.29 to 6.43 . Therefore, according to the thresholds proposed by Kline (2017), departures from multinormality in the distribution of the observed variables are not a major problem, and ML is appropriate method. A preliminary analysis of the data also sought to detect any ill-fitting items, based on item-to-total correlations and an exploratory factor analysis. This preliminary analysis sought items with cross-loadings and that correlated poorly with other items in each scale. It suggested a few items to delete, including "Family members agree with the family business goals, plans, and policies," from the original culture dimension of the F-PEC scale, and "To what extent does your business encourage a collectivist rather an individualist culture?" from the stewardship culture scale. Each exhibited low correlations with the other items on its respective scale. This procedure was also applied in previous studies (e.g., Chrisman et al., 2012). The remaining items underwent a six-factor confirmatory factor analysis (CFA), to check the psychometric properties of the scales for each construct. The CFA results indicate 
that all the scales used to measure particular constructs applied to one factor each (in support of construct unidimensionality), except for the culture scale, which was not unidimensional. These findings affirm previous theoretical investigations of the factor structure and reliability of the F-PEC. In contrast with studies that rely on item averages to measure different dimensions of culture (e.g., Klein et al., 2005), the current study seeks content variability (Holt et al., 2010), so culture is estimated as a second-order construct, comprising the first-order constructs of values, commitment, and family engagement. Figure 2 depicts the final specification of the measurement model in the AMOS 25.0 software.

[Insert Figure 2 about here]

Table 1 provides an overview of the theoretical constructs, associated item measures, and estimated results of the measurement model. Although the chi-square value for the model is statistically significant $\left(\chi^{2}=453.24, d f=359, p<.01\right)$, the remaining measures indicate that the measurement model performs well (incremental fit index $[\mathrm{IFI}]=.97$; goodness of fit index $[\mathrm{GFI}]=.85$; Tucker-Lewis index $[\mathrm{TLI}]=.97$ comparative fit index $[\mathrm{CFI}]=.97$, and root mean square error approximation $[\mathrm{RMSEA}]=.040)$. The standardized factor loadings are substantial (all loadings exceed .50 threshold) and highly significant $(p<$ .01 ), with $t$-statistics above 4 . All R-squared values exceed the .20 threshold (Hooper et al., 2008), indicating acceptable item reliabilities and support for the convergent validity of the measures.

[Insert Table 1 about here]

Table 2 contains the correlation coefficients, Cronbach's alphas, composite reliabilities (CR), and average variance extracted (AVE) estimates. The Cronbach's alphas exceed .70, except for power (.692). The CR of each scale is greater than .70. Thus, the 
scales are internally consistent (Fornell and Larcker, 1981). The AVEs for each construct exceed .50 , and the correlations between the constructs range from -.088 to .661 . Because the AVE is greater than the squared correlations between two constructs — that is, greater than the maximum shared variance (MSV), - these findings confirm the discriminant validity of the constructs (Fornell and Larcker 1981). In summary, the constructs are unidimensional, with acceptable levels of reliability, convergent validity, and discriminant validity.

[Insert Table 2 about here]

\subsection{Common method variance}

The data collection relied on a self-administered questionnaire, completed by individual respondents, so common method variance (CMV) could produce spurious relationships among the constructs. To account for this potential bias, this study uses both ex ante and ex post control procedures. Ex ante, several procedures are suggested by Podsakoff et al. (2003). First, a pre-test of the questionnaire in a pilot study with four respondents from family-owned SMEs confirmed the comprehensibility of the scale items. Second, the first page of the questionnaire assured respondents that their answers were anonymous, highlighted that there were no right or wrong answers, and emphasized that their answers should be honest. Third, the order of items to measure the F-PEC, mediators, and outcome constructs were counterbalanced to avoid contextual biases.

Ex post, the CMV assessment relied on several techniques (Podsakoff et al., 2003). First, Harman's single-factor test would indicate problematic CMV if an exploratory factor analysis with all variables revealed that the first factor extracted (without rotation) accounted for more than $50 \%$ of the variance among the original variables (Podsakoff and Organ, 1986). For this study, seven factors emerged with eigenvalues greater than 1 , and the 
percentages of variance explained by each factor were as follows: $26.17 \%, 11.22 \%, 10.06 \%$, $8.51 \%, 6.96 \%, 5.21 \%$, and $3.84 \%$. Second, using a CFA with all 29 items loaded on a single common factor, and applying a chi-square difference test, it is possible to compare the common factor model $\left(\chi^{2}=2371.22, d f=377\right)$ with the proposed measurement model and its six constructs $\left(\chi^{2}=453.24, d f=359\right)$. The proposed model fits better than the common factor model $\left(\Delta \chi^{2}=1917.98, d f=18, p<.001\right)$. Third, because the source of the CMV cannot be identified, we also use a single unmeasured latent method factor (Podsakoff et al., 2003), and estimate an additional measurement model that included the six latent variables (factors) and one additional factor (uncorrelated with the others), such that all 29 items load on this factor. If the additional uncorrelated factor accounts for more than $25 \%$ of the variance of the original variables, CMV may exist (Williams et al., 1989). However, the factor only accounted for $4.4 \%$ of the total variance. Thus, both ex ante and ex post control procedures suggest that $\mathrm{CMV}$ is not a major concern for this study.

\subsection{Structural model}

The proposed model (Figure 1) predicts that both stewardship motivation and stewardship culture mediate the effect of family influence (F-PEC scale) on financial performance. When a model has more than one mediator, the residuals associated with the mediators may covary (Preacher and Hayes, 2008). If the mediator residuals are fixed to zero, the model would be misspecified, with an unreasonable constraint. Therefore, in line with prior research (e.g., So et al., 2013), the model specification assumes correlated errors across the mediators. Figure 3 shows the structural model specification in the AMOS 25.0 software.

[Insert Figure 3 about here] 
Table 3 contains the standardized structural coefficient estimates and overall model fit statistics. The proposed model provides good fit to the collected data $\left(\chi^{2}=454.31, d f=\right.$ $362, p<.01 ; \mathrm{IFI}=.97 ; \mathrm{GFI}=.85 ; \mathrm{TLI}=.97 ; \mathrm{CFI}=.97, \mathrm{RMSEA}=.039)$.

[Insert Table 3 about here]

\subsection{Mediation results}

The proposed model predicts that the effect of family influence (F-PEC scale) on financial performance is fully mediated by stewardship behaviours. The test of these mediation effects, following James et al. (2006), estimates three further models (see Table 4, Panel A). Model 2 only includes the direct effect of F-PEC on financial performance; Model 3 includes the direct effects of F-PEC on stewardship motivation and stewardship culture, as well as on firm financial performance, but not the effect of the mediators on financial performance. Finally, Model 4 corresponds to the proposed model but also adds the direct effects of F-PEC on firm financial performance.

[Insert Table 4 about here]

The first step is to determine if the independent variables (F-PEC) exert a direct effect on the mediators (stewardship motivation and stewardship culture) and whether the mediators directly influence the dependent variable (financial performance), by estimating Model 1. Next, the analysis turns to whether the F-PEC has a direct influence on financial performance after excluding the mediators, according to the Model 2 estimation. Finally, the test determines whether the effect of the F-PEC on financial performance becomes less or non-significant when the mediators enter the model, which indicates partial or full mediation, respectively. The results suggest full mediation: The effect becomes nonsignificant. As a check, chi-square difference tests compare the full mediation Model 1 with 
the non-mediation Model 3 and with the partial mediation Model 4. As Panel B in Table 4 shows, Model 1 is significantly better than Model $3\left(\Delta \chi^{2}=9.78, \Delta d f=1, p<.01\right)$, but Model 4 is not significantly better than Model $1\left(\Delta \chi^{2}=1.07, \Delta d f=3, p>.05\right)$. That is, the paths from the F-PEC to financial performance are not significant after including the mediators, and the difference between Models 1 and 4 is not significant, at any conventional significance level, which offers further support for full mediation.

\section{Discussion}

Existing research is ambiguous with regard to whether family influence is beneficial or detrimental to the firm's financial performance (e.g., O’Boyle et al., 2012), so we undertake a study to investigate the ways family ownership, as an organizational variable, affects firm performance. Specifically, it tests the impact of the family's influence on firm financial performance, using the F-PEC scale, with the prediction of a mediating influence of stewardship relationships within the firm.

The results indicate that power positively influences stewardship motivation and stewardship culture, though not at a statistically significant at a conventional level $(\alpha=.05)$, so they cannot corroborate $\mathrm{H} 1 \mathrm{a}$ and $\mathrm{H} 2 \mathrm{a}$. The experience dimension reveals the expected positive sign ( $\mathrm{H} 1 \mathrm{~b}$ and $\mathrm{H} 2 \mathrm{~b}$ ), but it is not statistically significant for stewardship motivation (H1b). As a new generation assumes an active role in the family business, family members become increasingly distant from the founding generation, which weakens both family ties and commitment to the founder's vision. A greater dispersion of generations also might generate rivalry among family members. As the company develops and spans multiple generations, knowledge increases, but a more formal structure also may become necessary, to guarantee sustainability, reduce the risk of diminished family cohesion, or avoid divergences between values and family commitments. As predicted by stewardship theory, 
an involvement-oriented approach could encourage cooperation and involvement and thus facilitate the alignment of interests across all stakeholders, resulting in more proorganizational behaviour (stewardship culture, $\mathrm{H} 2 \mathrm{~b}$ ).

In line with $\mathrm{H} 1 \mathrm{c}$ and $\mathrm{H} 2 \mathrm{c}$, culture has a positive, statistically significant influence ( $p$ $<.01)$ on both stewardship motivation and stewardship culture. Family firms tend to feature high levels of trust, and if that trust is affective or relational, they may be governed by an involvement-oriented management philosophy — that is, by informal agreements based on affection and faith in the intentions of other parties. Employee stewards gain utility from fulfilling the purposes and objectives of the organization, and principals design an organizational structure that is both involvement oriented and empowering. The "secret sauce" of the firm's success is the family culture, which opens communication, streamlines decision making, acknowledges shared norms and values, and creates sustainable and inimitable competitive advantages (Miller and Le Breton-Miller, 2006).

With regard to the mediating variables, a stewardship motivation positively influences financial performance $(p<.01)$, in line with H3a and stewardship theory. These leaders and executives are not merely self-serving economic actors; they aspire to higher purposes and act altruistically to benefit their organizations and stakeholders. Stewards are intrinsically motivated by higher-level needs to ensure the collective good. They identify with their organizations and organizational objectives; they are committed to making their companies succeed, even if it means personal sacrifice. Such leaders commit deeply to their business missions, treasure their employees and stakeholders, and feel motivated. Their attitudes produce superior financial performance. The results pertaining to the effect of stewardship culture, as a pro-organizational behaviour, on financial performance cannot confirm H3b though. Perhaps collectivistic work environments increase free- 
riding, such that people reduce their effort when working collectively, because they perceive their contributions as less identifiable.

In summary, family firms enjoy better performance when they take advantage of and elicit stewardship attitudes among their owners and leaders. The most significant dimensions of F-PEC, in terms of enhancing firm performance through stewardship behaviour, are experience and culture. That is, family influence gained through experience and knowledge is more relevant than formal mechanisms of control, such as ownership, management, or power. The most distinctive element of family firms also arises from the family culture, such that the cultural dimensions determine the degree to which the values of families and companies overlap and thereby indicate the extent to which families identify with and value their companies. With these findings, this study contributes to extant literature by showing that the family's influence on firm financial performance is mediated by stewardship behaviour; it thus clarifies the pathways of this influence (Rau et al., 2018).

\section{Conclusions, practical implications, and limitations}

To address contradictory prior results regarding the relationship between family influence and firm financial performance, this study avoids the restrictions associated with using a single definition of family firms, by applying the F-PEC scale (Astrachan et al., 2002; Klein et al., 2005; Rau et al., 2018), which offers comparable findings across different family firms. Culture is not unidimensional, and for this study, it functions as a second-order construct, comprised of the first-order constructs of values, commitment, and family engagement. Theoretically, this article thus expands prior research by demonstrating the generalizability of the F-PEC (Holt et al., 2010).

Furthermore, to measure the mediating effect of stewardship on the impact of family influence on firm financial performance, this study adopts SEM methods. The results show 
that family influence enhances firm performance, fully mediated by stewardship behaviour. This extension of prior work (e.g., Eddleston et al., 2012; Rutherford et al., 2008) connects the concept of family influence to firm financial performance by leveraging stewardship theory. The results provide empirical evidence of prior arguments that a stewardship theory perspective is useful for understanding the financial performance of family firms (e.g., Corbetta and Salvato, 2004; Miller and Le Breton-Miller, 2006; Miller et al., 2008).

This study also is the first of its kind to be conducted in Portugal, a setting in which the business context differs from the Anglo-Saxon setting in which the F-PEC scale was initially conceived, particularly with regard to corporate governance regimes (Carney et al., 2015). The findings thus provide a novel view and explanation for the performancemaximizing behaviours exhibited by organizations, in which pro-organizational attitudes coexist with self-serving motives.

Regarding its practical implications, this study affirms that family culture is a critical determinant of firm performance. On the basis of an analysis of the behaviour of family SMEs, it reveals that interested entrepreneurs, managers, and consultants must acknowledge the financial and emotional (nonfinancial) elements of family influence. The survival of the family business depends on the nature of this balance (e.g., Holt et al., 2017). This study offers the first insights into how stewardship can mediate the relation between family influence and SME family firms' performance.

In terms of limitations, the survey took place during a recession and adjustment to the Portuguese economy; this highly uncertain context could affect respondents' views of the economic and financial performance of their companies. In addition, there is a clear need for longitudinal studies. The main determinants of stewardship behaviours (e.g., trust, altruism, and relational contracts) take time to develop and exert effects on firm performance (Chrisman et al., 2012), so family performance should be measured over longer time spans, 
reflecting these long-term orientations. It also would be helpful to expand the scope of the analysis to nonfinancial performance indicators (e.g., opportunity recognition, innovativeness, pro-activeness) that could offer more insights than short-term measures (e.g., sales growth), if the ultimate goal is to explain the determinants of value-enhancing organizational behaviour in family firms. 


\section{References}

AEF (2019), Portuguese Family Business Association (AEF) - Números e Factos, Retrieved from http:// https://empresasfamiliares.pt/ (Accessed September 27, 2019).

Anderson, J.C. and Gerbing, D.W. (1988), "Structural equation modeling in practice: A review and recommended two-step approach”, Psychological Bulletin, Vol. 103 No. 3, pp. 411-423.

Anderson, R. and Reeb, D. (2003), "Founding-family ownership and firm performance: Evidence from the S\&P 500", Journal of Finance, Vol. 58 No. 3, pp. 1301-28.

Anglin, A.H., Reid, S.W., Short, J.C., Zachary, M.A., and Rutherford, M.W. (2017), “An archival approach to measuring family influence: an organizational identity perspective", Family Business Review, Vol. 30 No. 1, pp. 19-36.

Armstrong, J.S. and Overton, T.S. (1977), "Estimating nonresponse bias in mail surveys", Journal of Marketing Research, Vol. 14 No. 3, pp. 396-402.

Astrachan, J.H., Klein, S.B. and Smyrnios, K.X. (2002), "The F-PEC scale of family influence: a proposal for solving the family business definition problem", Family Business Review, Vol. 15 No. 1, pp. 45-58.

Barnett, T., Eddleston, K. and Kellermanns, F.W. (2009), "The effects of family versus career role salience on the performance of family and nonfamily firms" Family Business Review, Vol. 22 No. 1, pp. 39-52.

Basco, R. (2017), "Where do you want to take your family firm? A theoretical and empirical exploratory study of family business goals", BQR Business Research Quarterly, Vol. 20 No. 1 , pp. $28-44$.

Bozer, G., Levin, L. and Santora, J. C. (2017), "Succession in family business: Multisource perspectives", Journal of Small Business and Enterprise Development, Vol. 24 No. 4, pp. 753-774. 
Carney, M., Van Essen, A., Gedajlovic, E.R. and Heugens, P. (2015), "What do we know about private family firms? A meta-analytical review”, Entrepreneurship Theory and Practice, Vol. 39 No. 3, pp. 513-544.

Chrisman, J.J., Chua, J.H. and Sharma, P. (2005), “Trends and directions in the development of a strategic management theory of the family firm", Entrepreneurship Theory and Practice, Vol. 29 No. 5, pp. 555-575.

Chrisman, J.J., Chua, J.H., Pearson, A. W. and Barnett, T. (2012), "Family involvement, family influence, and family-centered non-economic goals in small firms", Entrepreneurship Theory and Practice, Vol. 36 No. 2, pp. 267-293.

Chrisman, J.J., Kellermanns, F.W., Chan, K.C. and Liano, K. (2010), "Intellectual foundations of current research in family business: An identification and review of 25 influential articles", Family Business Review, Vol. 23 No. 1, pp. 9-26.

Chua, J.H., Chrisman, J.J. and Sharma, P. (1999), "Defining the family business by behaviour", Entrepreneurship Theory and Practice, Vol. 23 No. 4, pp. 19-39.

Corbetta, G. and Salvato, C. (2004), "Self-serving or self-actualizing? Models of man and agency costs in different types of family firms: A commentary on 'Comparing the agency costs of family and non-family firms: Conceptual issues and exploratory evidence"”, Entrepreneurship Theory and Practice, Vol. 28 No. 4, pp. 355-362.

Davis, J.H., Allen, M.R. and Hayes, H.D. (2010), "Is blood thicker than water? A study of stewardship perceptions in family business", Entrepreneurship Theory and Practice, Vol. 34 No. 6, pp. 1093-1116.

Davis, J.H., Schoorman, F.D. and Donaldson, L. (1997), "Toward a stewardship theory of management", Academy of Management Review, Vol. 22 No.1, pp. 20-47.

Eddleston, K.A. and Kellermanns, F.W. (2007), "Destructive and productive family relationships: A stewardship theory perspective", Journal of Business Venturing, Vol. 
22 No. 4, pp. 545-565.

Eddleston, K.A., Kellermanns, F.W. and Zellweger, T.M. (2012), "Exploring the entrepreneurial behavior of family firms: does the stewardship perspective explain differences?", Entrepreneurship Theory and Practice, Vol. 36 No. 2, No. 347-367.

European Union (2015), What is an SME? Retrieved from http://ec.europa.eu/growth/smes/business-friendly-environment/sme-definition (Accessed December 16, 2018).

Fama, E. and Jensen, M. (1983), "Agency problems and residual claims", Journal of Law and Economics, Vol. 26 No. 2, pp. 327-349.

Fornell, C. and Larcker, D. (1981), "Evaluating structural equation models with unobservable variables and measurement error", Journal of Marketing Research, Vol. 18 No. 1 , pp. 39-50.

Gama, A. P. M. and Galvão, J. (2012), "Performance, valuation and capital structure: Survey of family firms", Corporate Governance: The international Journal of Business in Society, Vol. 12 No. 2, pp. 199-214.

Gama, A. P. M. and Rodrigues, C. (2013), "The governance-performance relations in publicly listed family controlled firms: An empirical analysis", Corporate Governance: The International Journal of Business in Society, Vol. 13 No. 4, pp. $439-456$.

González-Cruz, T.F. and Cruz-Ros, S. (2016), "When does family involvement produce superior performance in SME family business?", Journal of Business Research, Vol. 69 No. 4, pp. 1452-1457.

Habbershon, T.G. and Williams, M. (1999), “A resource-based framework for assessing the strategic advantages of family firms", Family Business Review, Vol. 12 No. 1, pp. 125. 
Habbershon, T.G., Williams, M. and MacMillan, I.C. (2003), “A unified systems perspective of family firm performance”, Journal of Business Venturing, Vol. 18 No. 4, pp. 451465.

Holt, D. T., Pearson, A. W., Carr, J. C., and Barnett, T. (2017), "Family firm(s) outcomes model: Structuring financial and nonfinancial outcomes across the family and firm", Family Business Review, Vol. 30 No. 2, pp.182-202.

Holt, D.T., Rutherford, M.W. and Kuratko, D.F. (2010), "Advancing the field of family business research: Further testing the measurement properties of the F-PEC", Family Business Review, Vol. 23 No. 1, pp. 76-88.

Hooper, D., Coughlan, J. and Mullen, M. (2008), “Structural equation modelling: Guidelines for determining model fit", Electronic Journal of Business Research Methods, Vol. 6 No. 1, pp. 53-60.

IFERA (International Family Enterprise Research Academy) (2003), "Family Businesses Dominate: International Family Enterprise Research Academy (IFERA)", Family Business Review, Vol. 16 No. 4, pp. 235-240.

James, A.E., Jennings, J.E. and Jennings, P.D. (2017), "Is it better to govern managers via agency or stewardship? Examining asymmetries by family versus nonfamily affiliation”, Family Business Review, Vol. 30 No. 3, pp. 262-283.

James, L.R., Mulaik, S.A. and Brett, J.M. (2006), “A tale of two methods”, Organizational Research Methods, Vol. 9 No. 2, pp. 233-244.

Jensen, M. and Meckling, W. (1976), “Theory of the firm: Managerial behaviour, agency costs and ownership structure", Journal of Financial Economics, Vol. 3 No. 4, pp. 305 360.

Kellermanns, F.W., Eddleston, K.A., Sarathy, R. and Fran Murphy, F. (2012), "Innovativeness in family firms: A family influence perspective", Small Business 
Economics, Vol. 38 No. 1, pp. 85-101.

Klein, S.B., Astrachan, J.H. and Smyrnios, K.X. (2005), "The F-PEC scale of family influence: construction, validation, and further implication for theory", Entrepreneurship Theory and Practice, Vol. 29 No. 3, pp. 321-339.

Kline, R. (2017), Principles and practice of structural equation modeling ( $\left.3^{\text {rd }} \mathrm{ed}.\right)$, The Guildford Press, New York, NY.

Le Breton-Miller, I. and Miller, D. (2013), "Socioemotional wealth across the family firm life cycle: A commentary on "Family business survival and the role of boards"", Entrepreneurship Theory and Practice, Vol. 37 No. 6, pp. 1391-1397.

Le Breton-Miller, I., and Miller, D. (2009), “Agency vs. stewardship in public family firms: A social embeddedness reconciliation", Entrepreneurship Theory and Practice, Vol. 33 No. 6, pp.1169-1191.

Litz, R.A. (1995), “The family business: Toward definitional clarity”, Family Business Review, Vol. 8 No. 2, pp. 71-81.

Lussier, R.N. and Sonfield, M.C. (2006), "The effect of family business size as firms grow: a USA - France comparison", Journal of Small Business and Enterprise Development, Vol. 13 No. 3, pp. 314-325.

Madison, K., Holt, D.T., Kellermanns, F.W. and Ranft, A.L. (2016), "Viewing family firm behavior and governance through the lens of agency and stewardship theories", Family Business Review, Vol. 9 No. 1, pp. 65-93.

Madison, K., Kellermanns, F.W. and Munyon, T.P. (2017), "Coexisting agency and stewardship governance in family firms: an empirical investigation of individual-level and firm-level effects”, Family Business Review, Vol. 30 No. 4, pp. 347-368.

Mazzi, C. (2011), "Family business and financial performance : Current state of knowledge and future research challenges", Journal of Family Business Strategy, Vol. 2 No. 3, pp. 
$166-181$.

Mazzola, P., Sciascia, S., and Kellermanns, F. (2013), "Non-linear effects of family sources of power on performance", Journal of Business Research, Vol. 66 No. 4,pp. 568-574.

Miller, D. and Le Breton-Miller, I. (2006), "Family governance and firm performance: Agency, stewardship, and capabilities", Family Business Review, Vol. 19 No. 1, pp. $73-87$.

Miller, D., Le Breton-Miller, I. and Scholnick, B. (2008), "Stewardship vs. stagnation: An empirical comparison of small family and non-family businesses", Journal of Management Studies, Vol. 45 No. 1, pp. 51-78.

Molly, V., Uhlaner, L.M., De Massis, A. and Laveren, E. (2019), "Family-centered goals, family board representation, and debt financing” Small Business Economics, Vol. 53 No. 1, pp. 269-286.

Monreal-Pérez, J. and Sánchez-Marín, G. (2017), "Does transitioning from family to non-family controlled firm influence internationalization?", Journal of Small Business and Enterprise Development, Vol. 24 No. 4, pp. 775-792.

Muñoz-Bullon, F., Sanchez-Buenoa, M.J. and Suárez-González, I. (2018), “Diversification decisions among family firms: The role of family involvement and generational stage", BQR Business Research Quarterly, Vol. 21 No. 1, pp. 39-52.

Neubaum, D.O., Thomas, C.H., Dibrell, C. and Craig, J.B. (2017), “Stewardship climate scale: an assessment of reliability and validity", Family Business Review, Vol. 30 No. 1, pp. 37-60.

O’Boyle, E.H., Pollack, J.M. and Rutherford, M.W. (2012), "Exploring the relation between family involvement and firms' financial performance: A meta-analysis of main and moderator effects", Journal of Business Venturing, Vol. 27 No. 1, pp. 1-18. 
Pearson, A.W. and Marler, L.E. (2010), “A leadership perspective of reciprocal stewardship in family firms", Entrepreneurship Theory and Practice, Vol. 34 No. 6, pp. 1117 1124

Podsakoff, P.M. and Organ, D.W. (1986), "Self-reports in organizational research: Problems and prospects", Journal of Management, Vol. 12 No. 4, pp. 531-544.

Podsakoff, P.M., MacKenzie, S.B. Lee, J.-Y. and Podsakoff, N.P. (2003), “Common method biases in behavioral research: A critical review of the literature and recommended remedies”, Journal of Applied Psychology, Vol. 88 No. 5, pp. 879-903.

Preacher, K.J. and Hayes, A.F. (2008), “Asymptotic and resampling strategies for assessing and comparing indirect effects in multiple mediator models", Behavior Research Methods, Vol. 40 No. 3, pp. 879-891.

Rau, S.B., Astrachan, J.H. and Smyrnios, K.X. (2018), “The F-PEC revisited: From the family business definition dilemma to foundation of theory", Family Business Review, Vol. 31 No. 2, pp. 200-213.

Rutherford, M.W., Kuratko, D.F. and Holt, D.T. (2008), "Examining the link between "familiness" and performance: Can the F-PEC untangle the family business theory jungle?" Entrepreneurship Theory and Practice, Vol. 32 No. 6, pp. 1089-1109.

Sciascia, S. and Mazzola, P. (2008), "Family involvement in ownership and management: Exploring nonlinear effects on performance", Family Business Review, Vol. 21 No. 4, pp. 331-345.

Sharma P. and Nordqvist M. (2008), “A classification scheme for family firms: From family values to effective governance to firm performance”, in Tàpies J., Ward J.L. (ed.), Family values and value creation, Palgrave Macmillan, London.

Simon, H. (1997), Administrative behavior-A study of decision-making processes in administrative organizations $\left(4^{\text {th }}\right.$ ed.), New York: Free Press. 
So, K.K.F., King, C., Sparks, B. and Wang, Y. (2013), “The influence of customer brand identification on hotel brand evaluation and loyalty development", International Journal of Hospitality Management, Vol. 34, pp. 31-41.

Villalonga, B., and Amit, R. (2006), "How do family ownership, control and management affect firm value?", Journal of Financial Economics, Vol. 80 No. 2, pp. 385-417.

Westhead, P., and Howorth, C. (2006), "Ownership and management issues associated with family firm performance and company objectives", Family Business Review, Vol. 19 No. 4, pp. 301-316.

Williams, L., Cote, J. and Buckley, M. (1989), "Lack of method variance in self-reported affect and perceptions at work: Reality or artifact?”, Journal of Applied Psychology, Vol. 74 No. 3, pp. 462-468.

Zahra, S.A., Hayton, J.C., Neubaum, D.O., Dibrell, C. and Craig, J. (2008), "Culture of family commitment and strategic flexibility: The moderating effect of stewardship", Entrepreneurship Theory and Practice, Vol. 32 No. 6, pp. 1035-1054.

Zellweger, T.M., Eddleston, K.A. and Kellermanns, F.W. (2010), "Exploring the concept of familiness: Introducing family firm identity”, Journal of Family Business Strategy, Vol. 1 No. 1, pp. 54-63. 
Figure 1: Conceptual framework

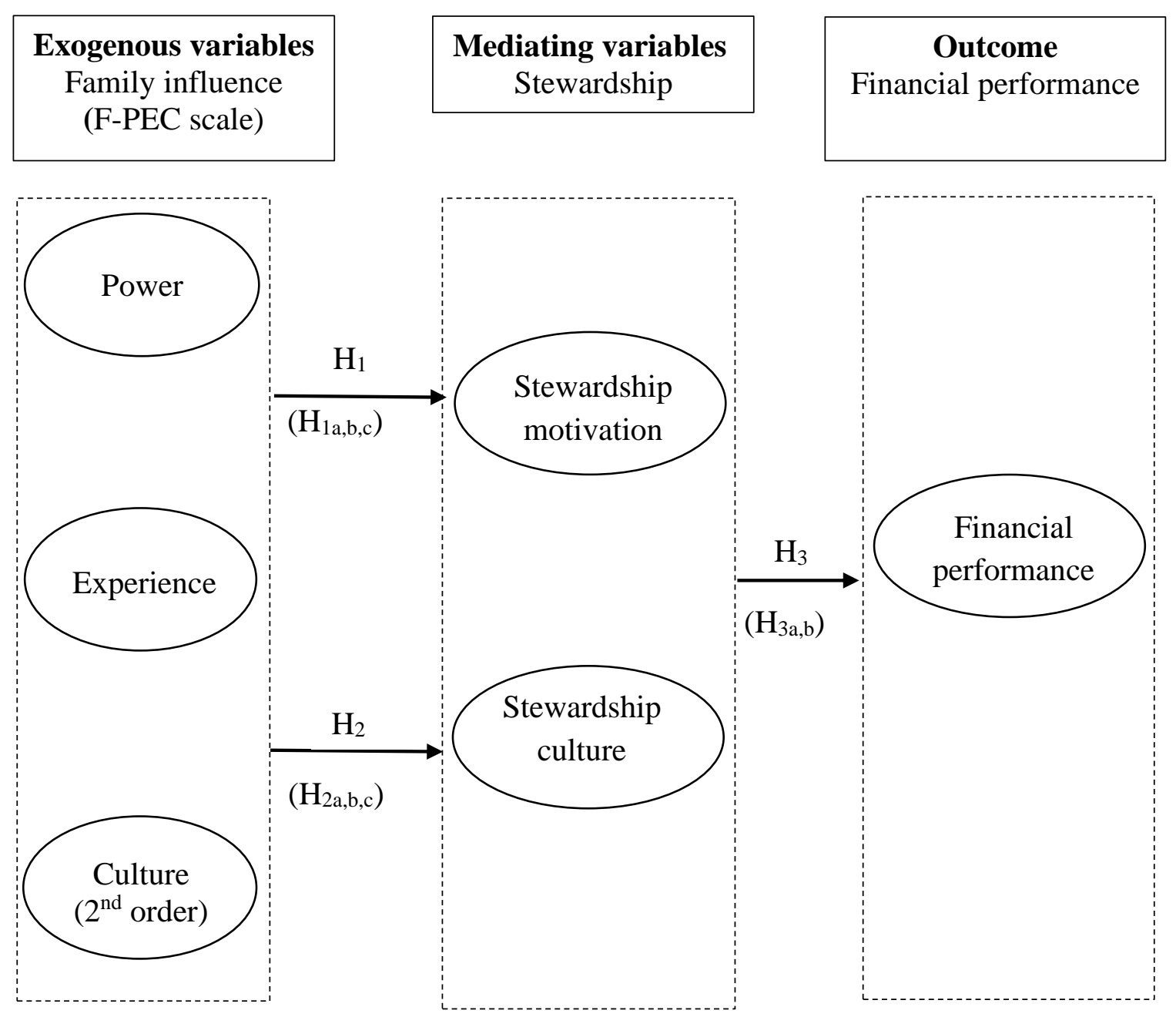


Figure 2: Measurement model specification in the AMOS software

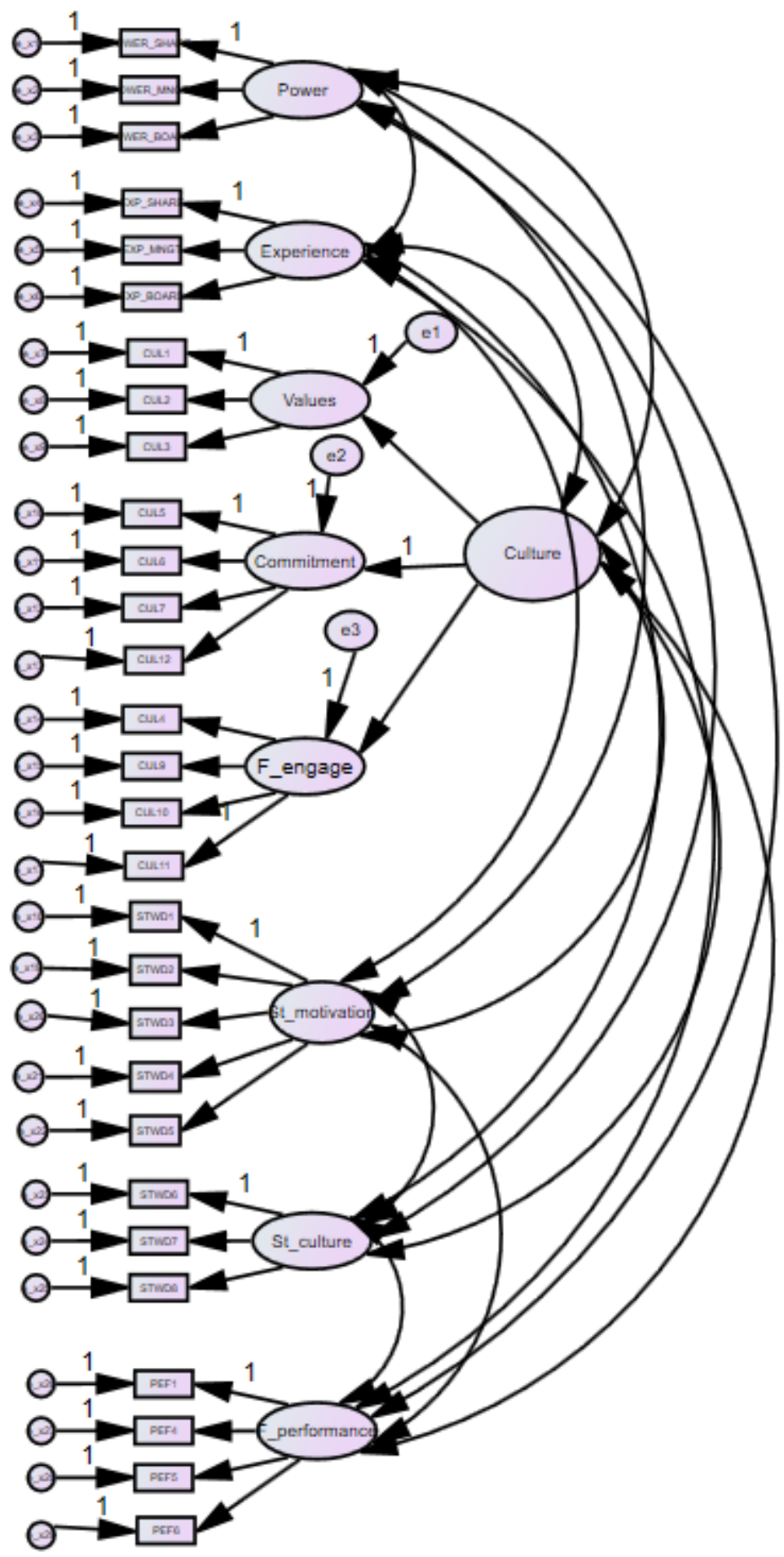

Legend: F_engage $=$ Family engagement; St_motivation $=$ Stewardship motivation; St_culture $=$ Stewardship culture; F_performance $=$ Financial performance. 
Figure 3: Structural model specification in AMOS software

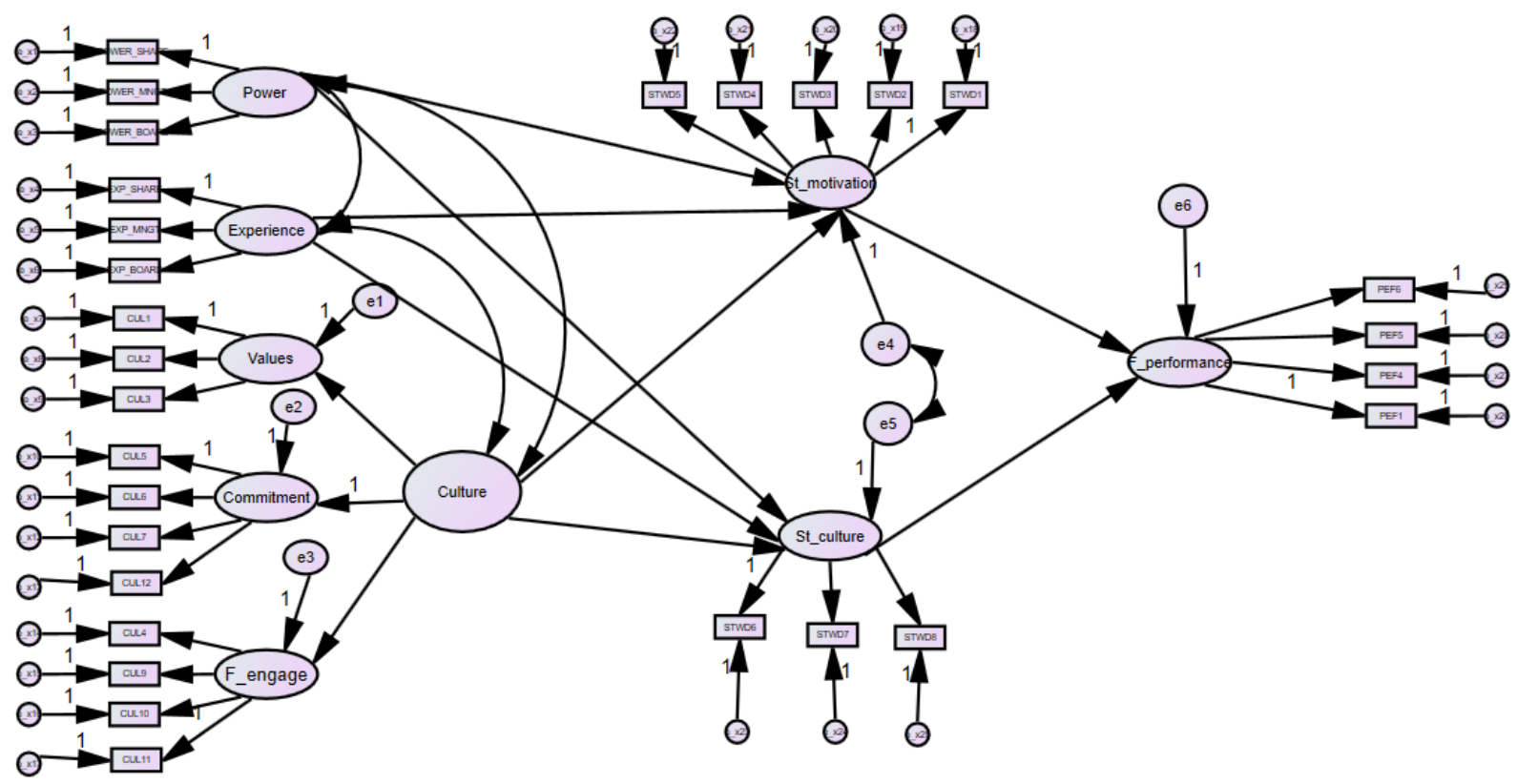

Legend: F_engage $=$ Family engagement; St_motivation $=$ Stewardship motivation; St $\_$culture $=$ Stewardship culture; F_performance $=$ Financial performance. 
Table 1: Standardized parameter estimates, critical ratios, and $\mathrm{R}^{2}$ values for the measurement model

\begin{tabular}{|c|c|c|c|c|}
\hline Construct & Items & $\begin{array}{l}\text { Standard } \\
\text { Loadings }\end{array}$ & $t$-Value & $\mathrm{R}^{2}$ \\
\hline \multirow[t]{3}{*}{ Power } & Family share ownership (percentage) & .847 & --- & .718 \\
\hline & Family on the board of directors (percentage) & .889 & 8.31 & .790 \\
\hline & Family on the management team (percentage) & .508 & 6.38 & .258 \\
\hline \multirow[t]{3}{*}{ Experience } & Generation(s) that own(s) the company & .952 & --- & .906 \\
\hline & Generation(s) active on the governance board & .949 & 23.27 & .901 \\
\hline & Generation(s) that manage(s) the company & .827 & 16.38 & .684 \\
\hline Culture & Values & .523 & 4.96 & .274 \\
\hline \multirow{2}{*}{ (second-order) } & Commitment & .942 & --- & .887 \\
\hline & Family engagement & .962 & 8.40 & .925 \\
\hline \multirow[t]{3}{*}{ Values } & Your family has influence on your business. & .558 & --- & .311 \\
\hline & Your family members share similar values. & .928 & 7.79 & .861 \\
\hline & Your family and business share similar values. & .907 & 7.81 & .823 \\
\hline \multirow[t]{4}{*}{ Commitment } & Family members feel loyalty to the family business. & .822 & --- & .675 \\
\hline & $\begin{array}{l}\text { Family members are proud to tell others that we are part of } \\
\text { the family business. }\end{array}$ & .777 & 10.82 & .604 \\
\hline & $\begin{array}{l}\text { There is so much to be gained by participating with the } \\
\text { family business on a long-term basis. }\end{array}$ & .563 & 7.35 & .317 \\
\hline & $\begin{array}{l}\text { Family members are willing to put in a great deal of effort } \\
\text { beyond that normally expected to help the family business } \\
\text { be successful. }\end{array}$ & 699 & 9.49 & .488 \\
\hline \multirow[t]{4}{*}{$\begin{array}{l}\text { Family } \\
\text { engagement }\end{array}$} & $\begin{array}{l}\text { Family members support the family business in } \\
\text { discussions with friends, employees, and other family } \\
\text { members. }\end{array}$ & .503 & 6.46 & .253 \\
\hline & $\begin{array}{l}\text { Family members really care about the fate of the family } \\
\text { business. }\end{array}$ & .634 & 8.43 & .402 \\
\hline & $\begin{array}{l}\text { Deciding to be involved with the family business has a } \\
\text { positive influence on my life. }\end{array}$ & .768 & 10.65 & .590 \\
\hline & $\begin{array}{l}\text { I understand and support my family's decisions regarding } \\
\text { the future of the family business. }\end{array}$ & .826 & --- & .683 \\
\hline \multirow[t]{5}{*}{$\begin{array}{l}\text { Stewardship } \\
\text { motivation }\end{array}$} & $\begin{array}{l}\text { To what extent does your business... } \\
\text { satisfy your need for achievement. }\end{array}$ & .870 & --- & .757 \\
\hline & satisfy your personal needs. & .859 & 14.79 & .738 \\
\hline & satisfy your opportunities for growth. & .866 & 15.00 & .749 \\
\hline & contribute to your self-image. & .851 & 15.56 & .725 \\
\hline & make you feel self-actualized. & .702 & 10.65 & .493 \\
\hline \multirow{4}{*}{$\begin{array}{l}\text { Stewardship } \\
\text { culture }\end{array}$} & To what extent does your business... & & & \\
\hline & allow employees to reach their full potential. & .804 & --- & 647 \\
\hline & foster a professionally oriented workplace. & .886 & 11.80 & .785 \\
\hline & inspire employees' care and loyalty. & .735 & 9.93 & .540 \\
\hline \multirow{4}{*}{$\begin{array}{l}\text { Financial } \\
\text { performance }\end{array}$} & Sales growth & .542 & --- & .293 \\
\hline & Profit margin & .823 & 7.53 & 677 \\
\hline & Return on asset growth & .983 & 8.11 & .966 \\
\hline & Return on equity growth & .933 & 7.99 & .871 \\
\hline
\end{tabular}

Model fit: $\chi^{2}=453.24 ; d f=359$; incremental fit index $=.97$; goodness-of-fit index $=.85$; Tucker-

Lewis index $=.97$; comparative fit index $=.97$; root mean square error approximation $=.040$. 
Table 2: Correlation matrix of constructs, CR, AVE, and MSV estimates

\begin{tabular}{lccccccccc}
\hline Construct & $X_{1}$ & $X_{2}$ & $X_{3}$ & $X_{4}$ & $X_{5}$ & $X_{6}$ & CR & AVE & MSV \\
\hline Power $\left(X_{1}\right)$ & .692 & & & & & & .80 & .59 & .01 \\
Experience $\left(X_{2}\right)$ & -.088 & .933 & & & & & .94 & .83 & .05 \\
Culture (second-order) $\left(X_{3}\right)$ & -.013 & .061 & --- & & & & .87 & .70 & .21 \\
Stewardship motivation $\left(X_{4}\right)$ & .061 & .055 & .458 & .912 & & & .92 & .69 & .44 \\
Stewardship culture $\left(X_{5}\right)$ & -.041 & .224 & .440 & .661 & .848 & & .85 & .66 & .44 \\
Financial performance $\left(X_{6}\right)$ & -.057 & .019 & .166 & .310 & .195 & .893 & .90 & .70 & .04 \\
\hline
\end{tabular}

Notes: Diagonal entries are Cronbach's alpha coefficients; $\mathrm{CR}=$ composite reliability; $\mathrm{AVE}=$ average variance extracted MSV $=$ maximum shared variance. 
Table 3: Structural model results

\begin{tabular}{lllll}
\hline Path & $\begin{array}{l}\text { Standardized } \\
\text { Coefficient }\end{array}$ & $\begin{array}{l}\mathrm{t} \text { - } \\
\text { Value }\end{array}$ & p-value & Hypotheses \\
\hline Power $\rightarrow$ SM & .069 & .88 & & $\mathrm{H}_{1 \mathrm{a}}: \mathrm{NS}$ \\
Power $\rightarrow$ SC & -.017 & -.21 & & $\mathrm{H}_{2 \mathrm{a}}: \mathrm{NS}$ \\
Experience $\rightarrow$ SM & .057 & .76 & & $\mathrm{H}_{1 \mathrm{~b}}: \mathrm{NS}$ \\
Experience $\rightarrow$ SC & .219 & 2.81 & $*$ & $\mathrm{H}_{2 \mathrm{~b}}: \mathrm{S}$ \\
Culture (second-order) $\rightarrow$ SM & .459 & 5.26 & $*$ & $\mathrm{H}_{1 \mathrm{c}}: \mathrm{S}$ \\
Culture (second-order) $\rightarrow$ SC & .438 & 4.87 & $*$ & $\mathrm{H}_{2 \mathrm{c}}: \mathrm{S}$ \\
$\mathrm{SM} \rightarrow \mathrm{FP}$ & .318 & 2.68 & $*$ & $\mathrm{H}_{3 \mathrm{a}}: \mathrm{S}$ \\
$\mathrm{SC} \rightarrow \mathrm{FP}$ & -.013 & -.11 & & $\mathrm{H}_{3 \mathrm{~b}}: \mathrm{NS}$ \\
\hline
\end{tabular}

$* p \leq .01$.

Notes: $\mathrm{SM}=$ stewardship motivation; $\mathrm{SC}=$ stewardship culture; $\mathrm{FP}=$ financial performance; $\mathrm{S}=$ supported; NS = not supported.

Model fit: $\chi^{2}=454,31, d f=362$; incremental fit index $=.97$; goodness-of-fit index $=.85$; Tucker-Lewis index $=.97$; comparative fit index $=.97$, root mean square error approximation $=.039$. 
Table 4: Mediation analysis results

Panel A: Estimated models

\begin{tabular}{lcccc}
\hline & $\begin{array}{c}\text { Model 1, } \\
\text { full } \\
\text { mediation }\end{array}$ & Model 2 & $\begin{array}{c}\text { Model 3, } \\
\text { non- } \\
\text { mediation }\end{array}$ & $\begin{array}{c}\text { Model 4, } \\
\text { partial } \\
\text { mediation }\end{array}$ \\
\hline Power $\rightarrow$ SM & .069 & & .070 & .072 \\
Power $\rightarrow$ SC & -.017 & & -.017 & -.016 \\
Experience $\rightarrow$ SM & .057 & & .057 & .057 \\
Experience $\rightarrow$ SC & $.219^{* *}$ & & $.219^{* *}$ & $.219^{* *}$ \\
Culture $($ second-order $) \rightarrow$ SM & $.459^{* *}$ & & $.467^{* *}$ & $.458^{* *}$ \\
Culture $($ second-order $) \rightarrow$ SC & $.438^{* *}$ & & $.441^{* *}$ & $.438^{* *}$ \\
Power $\rightarrow$ FP & ---- & -.055 & -.051 & -.078 \\
Experience $\rightarrow$ FP & - & .012 & .013 & .003 \\
Culture $($ second-order $) \rightarrow$ FP & ---- & $.164 *$ & $.186^{*}$ & .033 \\
$\mathrm{SM} \rightarrow$ FP & $.318^{* *}$ & & --- & $.324 * *$ \\
$\mathrm{SC} \rightarrow$ FP & -.013 & & -.038 \\
\hline
\end{tabular}

Panel B: Model comparison

\begin{tabular}{ccccrrrrrr}
\hline & $\chi^{2}$ & $d f$ & $\Delta d f$ & $\Delta \chi^{2}$ & GFI & IFI & TLI & CFI & RMSEA \\
\hline Model 1 & 454.31 & 362 & Base comparison & & .85 & .97 & .97 & .97 & .039 \\
Model 3 & 464.09 & 361 & 1 & 9.78 & .84 & .97 & .96 & .97 & .041 \\
Model 4 & 453.24 & 359 & 3 & 1.07 & .85 & .97 & .97 & .97 & .040 \\
\hline
\end{tabular}

$* p \leq .05 ; * * p \leq .01$, one-tailed tests.

Notes: $\mathrm{SM}=$ stewardship motivation; $\mathrm{SC}=$ stewardship culture; $\mathrm{FP}=$ financial performance; $\chi^{2}=$ chi-square; $d f=$ degrees of freedom; IFI = incremental fit index; GFI = goodness-of-fit index; TLI = Tucker-Lewis index; CFI = comparative fit index; RMSEA = root mean square error approximation. 